\title{
Variation of the performance of a PV panel with the number of bypass diodes and partial shading patterns
}

\author{
Haider Ibrahim \\ Dept. of Engineering and Design \\ University of Chichester \\ Bognor Regis, UK \\ United Kingdom \\ Ibrahimhk 2001@yahoo.com
}

\author{
Nader Anani \\ Dept. of Engineering and Design \\ University of Chichester \\ Bognor Regis, PO21 1HR, \\ United Kingdom \\ n.anani@chi.ac.uk
}

\begin{abstract}
- this paper presents an investigation into the variation of the performance of a $\mathrm{PV}$ module under different patterns of partial shading with variation in the number of bypass diodes. The investigation was performed using a MATLAB/Simulink simulation approach, which mitigates the need for complex numerical techniques. The single-diode model of a PV cell was used in the modelling. The performance is assessed in terms of the global maximum power yield and the number of local power peaks in the power-voltage characteristic of the PV module. Results indicate that increasing the number of bypass diodes can improve the energy yield of a module at the expense of increasing the number of local power peaks in the power-voltage curve. It is also found that the latter depends, not only on the pattern of partial shading, but also on its severity.
\end{abstract}

Keywords - PV module, partial shading, bypass diodes.

\section{INTRODUCTION}

Concerns over the adverse environmental effects of fossil fuels, coupled with their non-sustainability and the instability of their prices and supplies, motivated governments around the globe to invest heavily in renewable energy sources, such as wind, tidal and solar [1]. Renewable energy sources are sustainable and have minimal adverse effects on the environment. Recently, solar electric energy has been dominating the renewable power generation due to its falling prices and reduced complexity [2]. In a solar electric power plant, the basic generating unit is the photovoltaic (PV) cell, which converts the energy in the sunlight into electricity. Typically, a silicon PV cell provides a limited open-circuit voltage $V_{O C}$ of around $0.5 \mathrm{~V}$ and a short-circuit current $I_{S C}$ of few amperes, Fig. 1. Consequently, manufacturers of solar cells group a number of cells in series into an integrated PV panel, or module, in order to provide larger terminal voltage. Further, several such panels can be connected in series/parallel combinations, making up a PV array, to obtain the required terminal voltage and current. The terminal I-V characteristic of a PV cell (or panel/array) resembles that of a constant current source as shown in Fig. 1, which also includes the P$\mathrm{V}$ (power-voltage) curve.

It is clear that for maximum power to be extracted from a PV panel, the panel must be operated at its maximum power point (MPP). However, this point changes with variation in the incident irradiance and temperature [3]. Therefore, a maximum power point tracker (MPPT) is required to track and maintain operation of a PV panel at this point [4]. The problem is, however, compounded when a cell in a module, or a panel in an array, is subjected to different level of insolation than the rest of the cells or modules [5]. A phenomenon known as partial shading, which has adverse effects on the overall performance of a panel and may lead to its destruction [6].

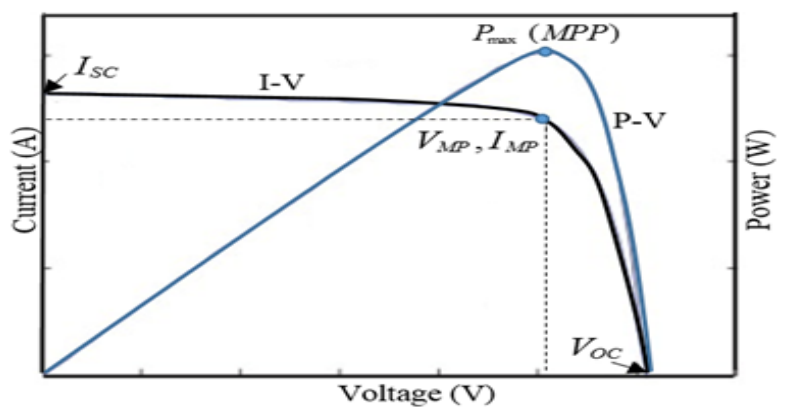

Fig. $1 \mathrm{I}-\mathrm{V}$ and $\mathrm{P}-\mathrm{V}$ characteristics of a PV cell/module.

When a cell is partially shaded, the overall current of the module becomes limited to the reduced current of the shaded cell [7]. For example, consider a string of three PV cells; C1, $\mathrm{C} 2$ and $\mathrm{C} 3$ as shown in Fig. 2 (a) with the middle cell represented by its single-diode equivalent circuit [8]. If the middle cell is partially shaded, its short-circuit current is reduced and the module's current is limited to this degraded value.

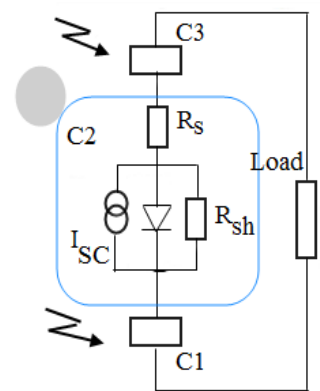

(a)



(b)

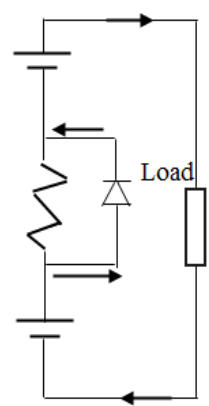

(c)
Fig. 2 a string of three PV cells and the use of a bypass diode.

The shaded cell become a consumer of electricity instead of a generator and this gives rise to joules heating, Fig. 2(b), which can irreversibly damage the cell and hence the whole module. To mitigate, this problem, an anti-parallel diode, Fig. 2 (c), can be deployed across a cell so that when it is shaded, the voltage drop across the shaded cell, will forwardbias the bypass diode, thus diverting the panel's current away from the shaded cell [9]. However, this is not without price; a conducting bypass diode reduces the terminal voltage of the panel, by a diode voltage drop, i.e. approximately $0.6 \mathrm{~V}$, and 
introduces a diode forward resistance in the path of the module's current. In addition, bypass diodes give rise to multiple maximum power peaks in the P-V curve, Fig. 3, which puts onerous demands on the design of an MPPT algorithm. Bypass diodes are normally integrated within a PV panel during the manufacturing process. However, in practice, PV panel manufacturers don't deploy a bypass across each cell. Instead, cells are grouped into strings, each string consists of a number of series-connected cells and one bypass diode is used across each string. For example, the KC200GT, which consists of 54 cells is divided into three strings of 18 cells each, with one bypass diode across each string [10]. Since, the deployment of these bypass diodes can have negative effects on the performance of a PV panel, the objective of the investigation presented in this paper, was to explore the variation of the performance of a PV panel with variation in the number of bypass diodes under varying patterns of partial shading. Following this section, Section II presents the methodology used during the investigation, while Section III presents the results of the work. Finally, Section IV summarises the outcomes of the investigation.

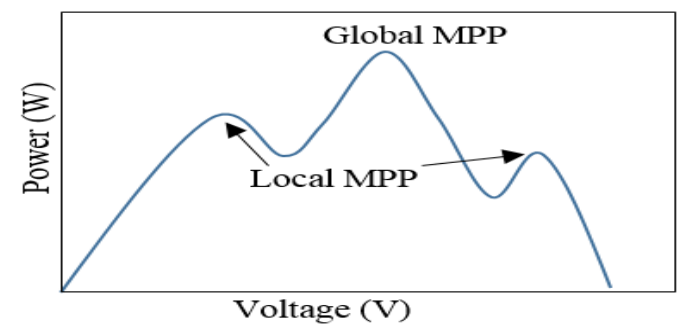

Fig. 3 Multiplicity of power peaks in the PV curve of a panel.

\section{Methodolgy}

The commercially available PV module, the KC200GT consists of 54 series-connected solar cells with three bypass diodes as shown in Fig.4 (a). In this investigation the effect of using, two, three, six, and nine bypass diodes, Fig. 4 (a-d) under four different shading patterns, as defined below, was investigated using MATLAB/Simulink alleviating the need for complex numerical methods.



(a)

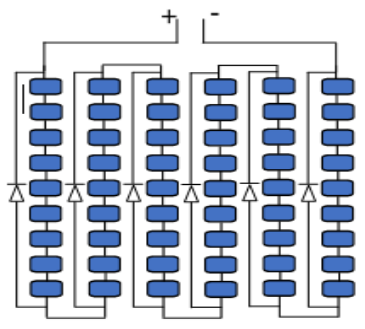

(c)



(b)



(d)
Fig. 4 The KC200GT PV panel with different number of bypass diodes.

The single-diode model of a PV cell was used in the simulation. The performance was assessed by determining the
$\mathrm{I}-\mathrm{V}$ and $\mathrm{P}-\mathrm{V}$ characteristics and the maximum power point of the PV module under different patterns of partial shading. The levels of shading used in the simulation are defined as:

Pattern 1: six cells in one string were exposed to $200 \mathrm{~W} / \mathrm{m}^{2}$ irradiance, while others subjected to full standard irradiance $\left(1000 \mathrm{~W} / \mathrm{m}^{2}\right)$.

Pattern 2: six cells in two strings were exposed to $200 \mathrm{~W} / \mathrm{m}^{2}$ irradiance, while other cells were fully illumination $\left(1000 \mathrm{~W} / \mathrm{m}^{2}\right)$.

Pattern 3: six cells in one string were exposed to $200 \mathrm{~W} / \mathrm{m}^{2}$ irradiance, another six cells in a different string were exposed to $400 \mathrm{~W} / \mathrm{m}^{2}$, and the rest of cells in the module were under full illumination.

Pattern 4: six cells in six different strings were exposed to different levels of illumination: $200 \mathrm{~W} / \mathrm{m}^{2}, 400 \mathrm{~W} / \mathrm{m}^{2}$, $600 \mathrm{~W} / \mathrm{m}^{2}$, and $800 \mathrm{~W} / \mathrm{m}^{2}$, while the rest of cells subjected to full illumination.

\section{SIMULATION RESULTS}

Fig. 5 shows the simulation results of partial shading pattern I. Under this partial shading pattern, only one bypass diode conducts; the one on the shaded string. It is observed that the P-V characteristics with different number of diodes exhibit one local power peak because the unshaded cells in the shaded string are forced to have the same characteristics as those of the shaded ones. The two-bypass diode scheme exhibits low maximum power point because of the large number of solar cells which are bypassed, while the ninebypass diode model gives best maximum power because of the smaller number of bypassed cells.
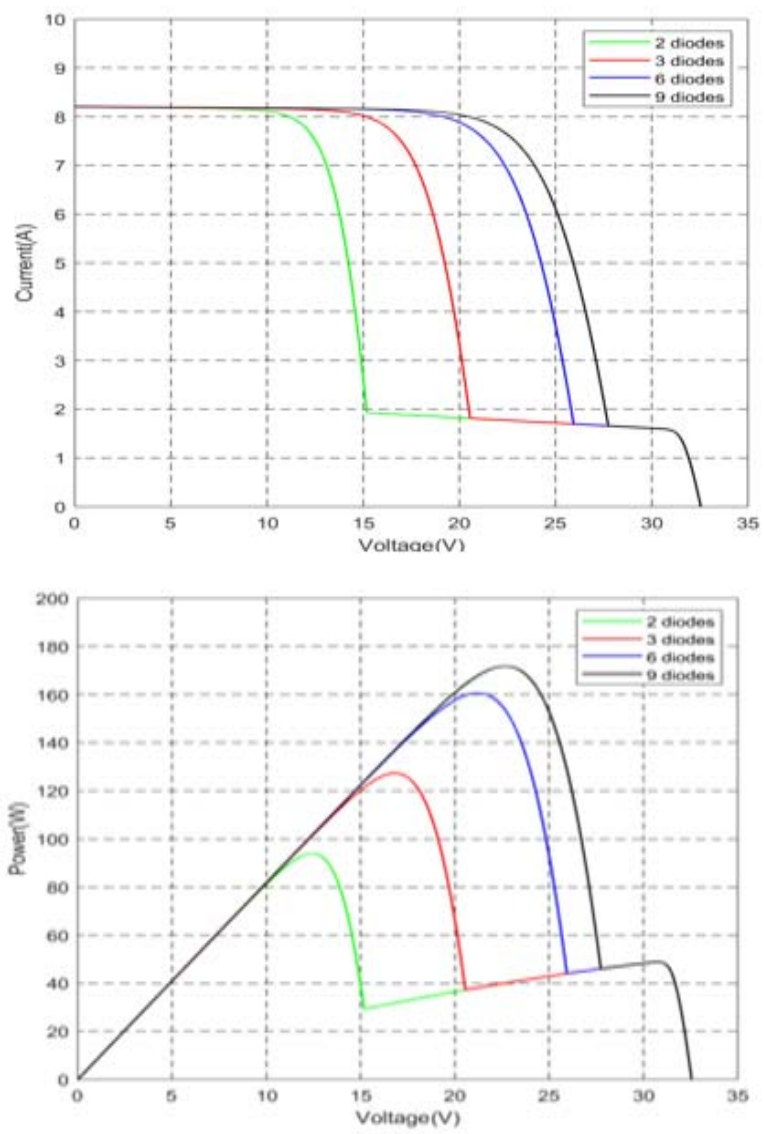

Fig. 5 (Top) I-V and P-V (bottom) characteristics under shading pattern I. 
Fig. 6 represent the characteristics of the PV module under partial shading pattern II. As can be seen, the two-bypass diode arrangement produces no local peaks, only the global MPP. This means that the bypass diodes are not in conduction state because of the uniform partial shading. All other schemes exhibit multiple peaks of power. In the three-bypass diode arrangement, although only two bypass diodes, on the shaded strings, will be conducting, only one extra local peak appears on the P-V curve because the two-shaded string have the same level of shading. Under this arrangement, the PV module produces lower global maximum power when compared with the six- and nine-bypass diode arrangements because nearly two-thirds of the module's cells (shaded and unshaded cells) have been bypassed.

Fig. 7 shows the I-V and P-V characteristics of the PV module under shading pattern III. As can be seen, the twobypass diode model exhibits only one extra peak indicating that only one bypass diode is conducting, i.e. the one on the string with the most shading, i.e. least irradiance. For the other bypass diode arrangements; i.e. the three-, six-, and nine-diode schemes, it is observed that there are two extra local power peaks in the $\mathrm{P}-\mathrm{V}$ characteristics because two bypass diodes are conducting under two different levels of shading. Therefore, the number of peaks in the P-V curve depends, not only on the number of conducting bypass diodes, but also on the level of partial shading.

Fig. 8 shows the six- and nine-bypass diode arrangements under shading patter IV. As can be seen, the P-V curve exhibits four local power peaks. This is because there are four bypass diodes in conduction state and there are four different levels of shading. The nine-diode scheme shows higher global maximum power than the six-diode scheme indicating that increasing number of bypass diodes improves the performance of a PV module when subjected to multiple levels of shading.
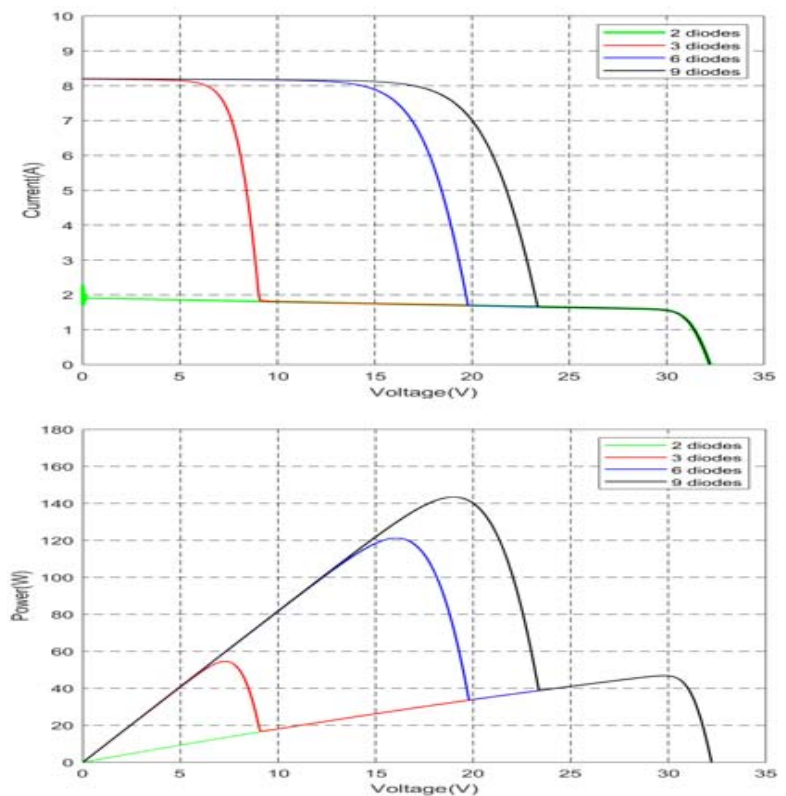

Fig. 6 (Top) I-V and P-V (bottom) characteristics under shading pattern II.
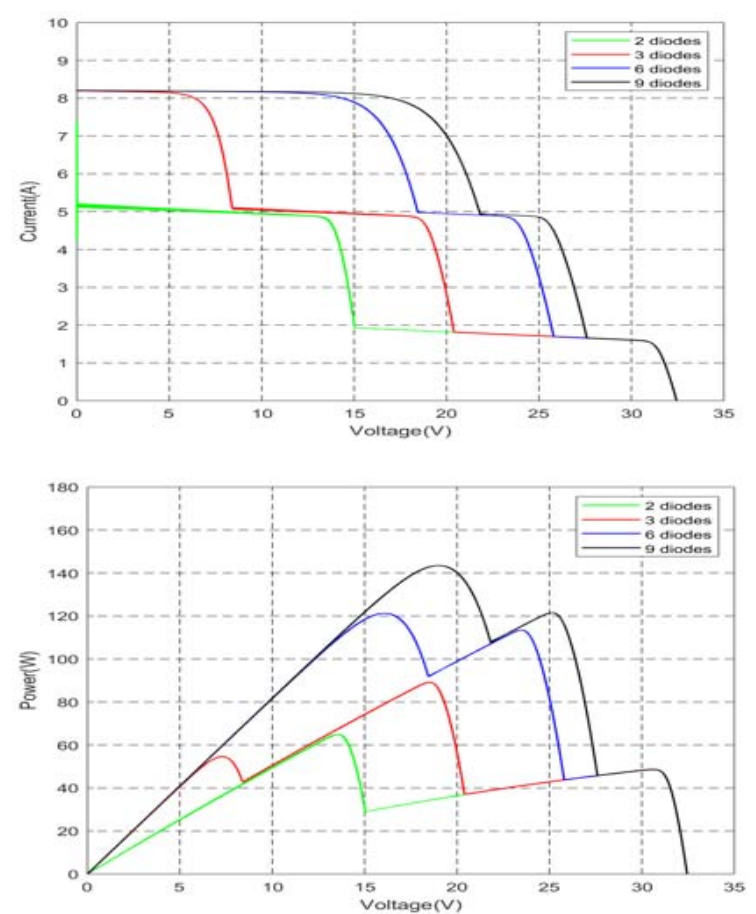

Fig. 7 (top) I-V and P-V (bottom) characteristics under shading pattern III.
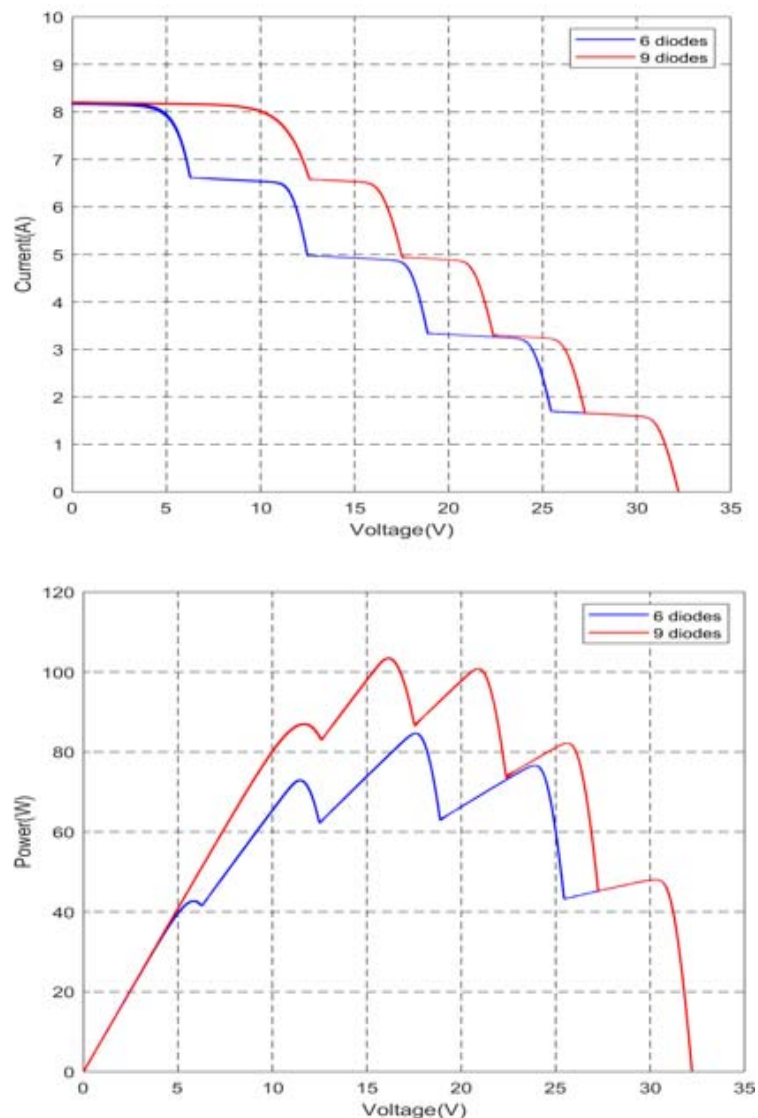

Fig. 8 (Top) I-V and P-V (bottom) characteristics under shading pattern IV. 
Table. 1 presents a comparison of the performance of different bypass diode schemes under the varying patterns of partial shading defined above. It is evident that the 9 bypass diode arrangements outperforms all others in reducing the adverse effects of partial shading. In addition, the level of partial shading also determines the number of local power peaks and the value of the global maximum power point. The main drawbacks of increasing the number of bypass diodes in a PV panel is increasing the manufacturing cost and increasing the number of local power peaks which complicates the design of the MPPT algorithm. TABLE I. SIMULATION RESULTS OF DIFFERENT NUMBER OF
BYPASS DIODES OF PV MODULE UNDER DIFFERENT PARTIAL SHADING PATTERNS

\begin{tabular}{|l|l|l|}
\hline Shading pattern & No. of diodes & $\boldsymbol{P}_{\max }(\boldsymbol{W})$ \\
\hline \multirow{4}{*}{ Pattern 1 } & 2 Diodes & 94 \\
& 3 Diodes & 127 \\
& 6 Diodes & 161 \\
& 9 Diodes & 172 \\
\hline \multirow{5}{*}{ Pattern 2 } & 2 Diodes & 47 \\
& 3 Diodes & 55 \\
& 6 Diodes & 121 \\
& 9 Diodes & 143 \\
\hline \multirow{3}{*}{ Pattern 3 } & 2 Diodes & 65 \\
& 3 Diodes & 89 \\
& 6 Diodes & 121 \\
& 9 Diodes & 144 \\
\hline \multirow{3}{*}{ Pattern 4 } & 2 Diodes & ---- \\
& 3 Diodes & ---- \\
& 6 Diodes & 85 \\
& 9 Diodes & 104 \\
\hline
\end{tabular}

\section{CONCLUSIONS}

The paper presented an investigation of the variation of the performance of a PV module with variation in the number of bypass diodes under varying conditions of partial shading. The performance was assessed in terms of the energy yield of the module and the number of local power peaks on its $\mathrm{P}-\mathrm{V}$ characteristic.
It is concluded that, increasing the number of bypass diode, although increases the number of local power peaks, it improves the output power of a PV module by reducing the effect of partial shading. Further, it was evident that the number of local power peaks depends on both, the number of bypass diodes and the severity of the level of shading.

\section{REFERENCES}

[1] M. Höök and X. Tang, "Depletion of fossil fuels and anthropogenic climate change," Energy Policy, vol. 52, pp. 797-809, 2013.

[2] U. Nations, "Global Trends in Renewable Energy Investment," UN, New York, 2018.

[3] H. Ibrahim and N. Anani, "Variations of PV module parameters with irradiance and temperature," Energy Procedia, vol. 134, pp. 276-285, 2017.

[4] J. Jayakumaran, "A Comprehensive Review on Maximum Power Point Tracking Algorithms for Photovoltaic Cells," in 2018 International Conference on Computation of Power, Energy, Information and Communication (ICCPEIC), Chennai, 2018.

[5] N. Anani and M. Burns, "Modelling and simulation of photovoltaic arrays under varying conditions," Elsevier Energy Procedia, vol. 42, no. 1, pp. 397-405, 2013.

[6] J. Ma, X. Pan, K. L. Man, X. Li, H. Wen and T. O. Ting, "Detection and Assessment of Partial Shading Scenarios on Photovoltaic Strings," IEEE Transactions on Industry Applications, vol. 54, no. 6, pp. 6279-6289, 2018.

[7] S. Silvestre, A. Boronay and A. Chouder, "Study of bypass diodes configuration on PV modules," Applied Energy, vol. 86, no. 9, pp. 1632-1640, 2009.

[8] S. Shongwe and M. Hanif, "Comparative Analysis of Different Single-Diode PV Modeling Methods," IEEE Journal of Photovoltaics, vol. 5, no. 3, pp. 938-946, 2015.

[9] K. A. Kim and P. T. Krein, "Reexamination of Photovoltaic Hot Spotting to Show Inadequacy of the Bypass Diode," IEEE Journal of Photovoltaics, vol. 5, no. 5, pp. 1435-1441, 2015.

[10] "KYOCERA Multicrystal," [Online]. Available: https://www.kyocerasolar.com/dealers/productcenter/archives/spec-sheets/KC200GT.pdf. [Accessed 20 April 2019]. 